\title{
Field Studies of the Co-Occlusion Strategy with a Genetically Altered Isolate of the Autographa californica Nuclear Polyhedrosis Virus
}

\author{
H. ALAN WOOD,${ }^{1}$ PATRICK R. HUGHES, ${ }^{1}$ AND ANTHONY SHELTON ${ }^{2}$
}

\begin{abstract}
Environ. Entomol. 23(2): 211-219
ABSTRACT The first field study of a genetically altered virus in the United States was performed with an isolate of the Autographa californica nuclear polyhedrosis virus (AcMNPV), which lacks a polyhedrin gene. In the first year of the study, three applications of $7.4 \times 10^{11}$ AcMNPV polyhedra containing $48 \%$ genetically altered and $52 \%$ wild-type virus particles (co-occluded) were made on a 0.1 -ha circular plot of cabbage plants. The application area was surrounded by a 0.7 -ha circular buffer zone. Before each application, the plants in the application area were infested with 4,500 third-instar Trichoplusia ni (Hübner) larvae. After each application, $100 \%$ of the $T$. $n i$ test larvae sampled $5 \mathrm{~d}$ after infection were infected with AcMNPV and produced progeny polyhedra containing an average of $42 \pm 17.6 \%$ genetically altered virus particles. At the end of the lst yr, the progeny polyhedra population in the application area was estimated at $1.6 \times 10^{13}$ polyhedra. In the 2 nd $y r$, the application and buffer sites were replanted with cabbage plants. At four times during the growing season, the plants were seeded with $T$. ni larvae or eggs. Less than $2 \%$ of the test larvae became infected with AcMNPV. Polyhedra were extracted from soil samples collected in the application and buffer areas. Using neonate larval bioassays with the soil extracts, it was estimated that the soil in the application and buffer areas contained an average of $1,652 \pm 3,370$ and $832 \pm 2,539$ biologically active polyhedra per gram dry weight, respectively. Seventy-five larvae infected with polyhedra extracted from application area soil samples produced progeny polyhedra containing a mean of $9 \pm$ $19 \%$ genetically altered virus particles. In the $3 \mathrm{rd}$ yr, the application area soil samples contained an average of $1,671 \pm 3,274$ biologically active polyhedra per gram dry weight. Eighty-four progeny polyhedral samples contained a mean of $6 \pm 14 \%$ genetically altered virus particles. The co-occlusion strategy did not alter the environmental persistence of the polyhedra containing both wild-type and polyhedrin-minus virus particles. However, the data show a decline in the percent of polyhedrin-minus particles in the polyhedra and demonstrate that the persistence of a polyhedrin-minus virus in a cycling virus population is limited by the co-occlusion process. The environmentally desirable attributes of using the co-occlusion process for genetically enhanced baculovirus pesticides and possible problems are discussed.
\end{abstract}

KEY WORDS Autographa californica nuclear polyhedrosis virus, baculovirus, genetically engineered

LOSSES IN AGRICULTURAL and forest production caused by phytophagous insects are estimated at billions of dollars per year. The control measures presently used to limit these losses are generally costly and are often undesirable for reasons of environmental damage, risk to public health, or mediocre effectiveness. Baculoviruses are among the most promising alternatives to chemical insecticides (Cunningham 1982, Hüber 1986, Leisy \& van Beek 1992). Based on their lack of health safety and environmental problems (Groner 1986), the following

\footnotetext{
${ }^{1}$ Boyce Thompson Institute for Plant Research, Ithaca, NY 14853.

2 Cornell University New York State Agricultural Experiment Station, Geneva, NY 14456.
}

four baculoviruses have been registered by the U.S. Environmental Protection Agency: the gypsy moth, Lymantria dispar (L.), the bollworm, Helicoverpa zea (Boddie), the European pine sawfly, Neodiprion sertifer (Geoffroy), and the Douglas-fir tussock moth, Orgyia pseudotsugata (McDunnough), nuclear polyhedrosis viruses (NPV).

Despite their safety and potential effectiveness, there has been limited commercial use of baculovirus pesticides. A major problem with commercialization has been that insects are not killed quickly and continue to damage crops for 5 to $15 \mathrm{~d}$ after infection. There have been several attempts to improve the pesticidal properties of baculoviruses by the insertion of pesticidal genes into the viral genomes of the Autographa 
californica (Ac) nuclear polyhedrosis virus (MNPV) and Bombyx mori MNPV. These genes have included the Buthus eupeus insect toxin-1 (Carbonell et al. 1988), the Manduca sexta diuretic hormone (Maeda 1989), the Bacillus thuringiensis ssp. kurstaki HD-73 delta-endotoxin (Merryweather et al. 1990), the Heliothis virescens juvenile hormone esterase (Hammock et al. 1990), the Pyemotes tritici TxP-I toxin (Tomalski \& Miller 1991) and Androctonus australis neurotoxin (Stewart et al. 1991, Maeda et al. 1991) genes. These genes were inserted into the viral genomes under the control of the polyhedrin or p10 gene promoters. The polyhedrin and plo genes are both under the control of late, strong transcriptional promoters and are nonessential for virus replication.

Under laboratory conditions, some of these recombinant viral pesticides kill their hosts faster or cause a faster cessation of feeding than the wild-type virus. Accordingly, there is interest in developing them as commercial pesticides. However, the field testing and commercial use of these recombinant pesticides as well as other genetically engineered microorganisms necessitates evaluations of the potential effects these organisms might have on human health and the environment (Wood 1991, Wood \& Granados 1991, Wood \& Hughes 1993). There are concerns that engineered organisms might displace related organisms from their niches in nature, thereby causing ecological perturbations. Also, if the engineered microorganism is discovered to have unwanted properties after its release, it may be difficult to eliminate it from the environment. Another issue is the potential for the foreign genetic material to be transferred from the released organism to other organisms with unpredicted consequences.

Co-occlusion has been proposed as a strategy that can be used to limit the persistence of the engineered baculovirus in the environment (Hamblin et al. 1990). The majority of the above mentioned, genetically altered baculoviruses lack a functional polyhedrin gene whose product is required for occlusion of virus particles within polyhedra. Under field conditions non-occluded virions are rapidly inactivated (Bishop et al. 1988). Baculoviruses lacking a polyhedrin gene can be stabilized by the co-occlusion process (Miller 1988, Hamblin et al. 1990). Co-occlusion occurs following co-infection of host cells with both the wild-type (containing a polyhedrin gene) and altered (lacking a polyhedrin gene) virus. Late in the replication cycle, the polyhedrin protein produced by the wild-type virus may occlude both types of virus particles. Persistence of the polyhedrin-minus virus in the virus population is determined by subsequent levels of co-infection and co-occlusion in successive virus passages. Laboratory studies with a polyhedrin-minus and wild-type isolate of the

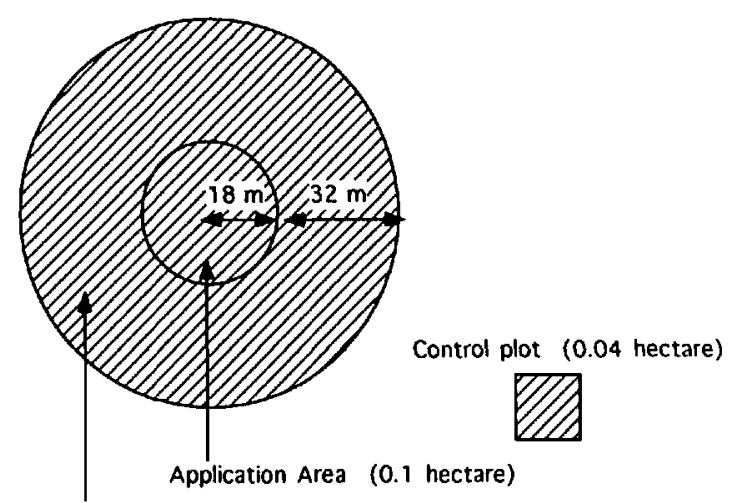

Buffer Zone ( 0.7 hectare)

Fig. 1. Experimental plot design

AcMNPV (Hamblin et al. 1990) indicated that there would be a low probability of persistence under field conditions.

A release project was conducted to validate the laboratory-based persistence model under field conditions. A genetically altered isolate of AcMNPV, which had a deleted polyhedrin gene but no foreign gene insert, was used. The altered virus was co-occluded with the wild-type AcMNPV. Polyhedra containing both virus types were sprayed onto plants in the field, and the persistence of each virus type was evaluated over a 3-yr period.

\section{Materials and Methods}

Viruses and Host. The wild-type virus was the 1A clone of AcMNPV (Wood 1980). The genetically altered form of the $1 \mathrm{~A}$ clone was the Ac-E10 virus, which lacked a functional polyhedrin gene (Hamblin et al. 1990). Polyhedra containing cooccluded wild-type and Ac-E10 virus particles in a ratio of 52:48, respectively, were produced in laboratory-reared T. ni larvae according to Hamblin et al. (1990). Polyhedra containing only wild-type virions were prepared using the same procedures.

Field Site. The field site was located at the Vegetable Research Farm of the New York State Agricultural Experiment Station in Geneva, NY. The experimental plot consisted of a circular, 0.8-ha planting of cabbage plants ('Atria') with $46 \mathrm{~cm}$ between plants and $91 \mathrm{~cm}$ between rows (Fig. 1). The center of the experimental plot was a circular, 0.1-ha virus application area. The remainder of the experimental plot consisted of a 0.7-ha buffer zone. A control plot consisting of a 0.04-ha square planting of cabbage was located $\approx 60 \mathrm{~m}$ from the edge of the buffer zone. Both plots were hand weeded throughout the growing season.

The large application area was required to establish a high concentration of virus polyhedra within a defined area. An even larger buffer zone 
was required to monitor virus dispersal. Because of the large size of the plot, the magnitude of sampling and DNA analyses as well as associated costs precluded replication. The experiment was designed to test a trend predicted by laboratory results (Hamblin et al. 1990)-namely, that the proportion of co-occluded, polyhedrin-minus virus would decrease in a vertically transmitted virus population. Because the purpose of this study was not quantitative in nature and given the above constraints, a single experimental plot was deemed sufficient.

To create a high polyhedra population in the application area and control plot, one-third of the cabbage plants in the application area $(\approx 900$ plants) and in the control plot ( $\approx 90$ plants) were inoculated with late-third instar $T$. ni larvae (five per plant) before each of the three virus applications. These larvae were raised under virus-free laboratory conditions before being transferred to the field.

At the end of the growing season, the cabbage plants in the test site were mowed and the residue incorporated into the soil to a depth of $15 \mathrm{~cm}$ by disking. In this way, the progeny virus polyhedra produced during the 1st yr were incorporated into the top layer of soil. In the spring of the 2nd yr (1990), the application and buffer areas were replanted with cabbage.

Virus Applications. Polyhedra containing both genetically altered and wild-type virus particles were applied to the plants in the application area on 9 August, 31 August, and 18 September 1989. The polyhedra were applied with a backpack $\mathrm{CO}_{2}$ sprayer ( $\mathrm{R} \& \mathrm{D}$ Sprayers, Opelousas, LA) delivering 136.6 liters per hectare at $2.8 \mathrm{~kg} / \mathrm{cm}^{2}$. Applications were made using three hollow cone nozzles per row, one nozzle over and one on each side of the row. The nozzle specifications indicated an aerosol droplet size of 360 microns.

The application mixture contained Bond sticker spreader (Loveland Industries, Loveland, CO) $(0.74 \mathrm{ml} /$ liter) and skim milk (1.93 ml/liter) for UV light protection. For each of the three applications, the co-occluded virus mixtures were applied to the 0.1-ha application area at a rate of $7.4 \times 10^{12}$ polyhedra per hectare. Polyhedra containing only wild-type virus particles were applied to the control plot at the same rate.

Detection of Aerosol Dispersal. To detect application drift, aerosol deposition samples were taken in the buffer area, which was sectored by 16 spokes radiating from the center of the application area. During the first application of polyhedra, $100-\mathrm{mm}$ petri plates containing high wheat germ diet were placed at a height of $15 \mathrm{~cm}$ above ground level at $0,3,6,9,12,18,24$, and 30 $\mathrm{m}$ along the 16 sectors radiating from the edge of the application area. For the second and third applications, additional samples were taken at $40 \mathrm{~m}$ along each of the 16 sectors, and again at 49 and $58 \mathrm{~m}$ along the three downwind sectors at the start of the spraying. Wind speed and direction were measured with an Omnidata Easy Logger (Omnidata International, Logan, UT) equipped with a Model 6301 windvane and Model 6101 three-cup anemometer.

The plates were opened just before spray application and closed immediately after the application; the procedure was repeated with each application. In the laboratory, 10 neonate $T . n i$ larvae were placed on each plate. The plates were then incubated at $29^{\circ} \mathrm{C}$ until pupation or death of all test animals. Larval deaths at $24 \mathrm{~h}$ after incubation were assumed to be attributable to nonviral causes. Positive control plates were contaminated with known concentrations of wild-type polyhedra, and the sensitivity limit of this assay was determined to be 0.6 polyhedra per $100 \mathrm{~mm}^{2}$ surface area. Multiple larvae were used per plate to maximize sensitivity of the assay to the presence of polyhedra.

Monitoring of Insect Populations. After each application, the $T$. ni larvae were monitored daily. When the first dead larva was detected, 200 and 50 larval samples from the application site and from the control site, respectively, were collected and placed individually in 30-ml cups containing insect diet. The samples were incubated in the laboratory at $29^{\circ} \mathrm{C}$ and percent mortality recorded daily until all larvae either died or pupated. The percent mortality was used to estimate the percent infection at $5 \mathrm{~d}$ post spraying. The progeny polyhedra were analyzed to determine the presence and percentage of occluded genetically engineered virus particles.

Monitoring of insect populations for viralinduced mortality was conducted in plots of sweet corn, alfalfa, cucumbers, beans, wheat, lettuce, strawberries, and beets immediately surrounding the test site.

Collection of Soil Samples. Before the start of the experiment and in the spring of the $2 \mathrm{nd}$ yr (1990), the soil in the test site was monitored for the presence of a naturally occurring population of AcMNPV or other baculovirus(es), which could infect $T$. ni larvae. Soil samples from the top $15 \mathrm{~cm}$ were collected from 25,30 , and 19 evenly spaced locations within the application area, buffer zone and control plot, respectively. In the spring of the 3rd $\mathrm{yr}$ (1991), soil samples were taken at the same 74 locations sampled in the 1st 2 yr plus an additional 32 locations evenly spaced throughout the buffer zone.

Extraction of Polyhedra from Soil Samples. Soil samples of $50 \mathrm{~g}$ dry weight were placed in 250-ml Erlenmeyer flasks and resuspended in $100 \mathrm{ml}$ of $0.1 \%$ (wt/vol) sodium dodecyl sulfate (SDS) solution. Following resuspension, the sample was sonicated at 50 watts for $30 \mathrm{~s}$ (Heat Systems, Model W185, Plainview, NY). The samples were left undisturbed for $20 \mathrm{~min}$, after which the supernatant was collected by aspiration. A second $100-\mathrm{ml}$ aliquot of $0.1 \%$ SDS solu- 
tion was then added to the soil in the flask, followed by sonication, settling for $30 \mathrm{~min}$, and collection of the supernatant. The supernatants of the two extractions were combined and centrifuged at $180 \times \mathrm{g}$ for $5 \mathrm{~min}$. The supernatants were then centrifuged at $5,000 \times g$ for $20 \mathrm{~min}$. The pellets were resuspended in $200 \mathrm{ml}$ of water, and the samples were again pelleted at $5,000 \times g$ for $20 \mathrm{~min}$. The pellets were then resuspended in $10 \mathrm{ml}$ of water and stored at $4^{\circ} \mathrm{C}$.

Bioassays of Soil Samples. The soil extract solutions were sonicated for $10 \mathrm{~s}$ at 50 watts immediately before dispensing $200 \mu \mathrm{l}$ ( $1 \mathrm{~g}$ dry weight equivalent) onto the surface of wheat germ diet in 30-ml cups. The suspension was evenly distributed over the diet surface and allowed to dry at room temperature for 1-2 h. Thirty replicate cups were prepared for each soil sample, and one neonate T. ni larva was placed in each cup. Larvae were examined after $24 \mathrm{~h}$, and the occasional dead larva was eliminated from the test as nonviral mortality. The larvae were incubated at $29^{\circ} \mathrm{C}$ until death or pupation.

A calibration line (probit mortality versus log of polyhedra concentration) was obtained by measuring larval responses to varying known concentrations of polyhedra added to control soil samples after extraction. This calibration line was used to convert percent mortality from soil samples to estimated dose in polyhedra. The extraction procedure efficiency was estimated from bioassays of soil samples to which varying known concentrations of polyhedra were added before the extraction procedure. The dose calculated from the calibration line was divided by this extraction efficiency to estimate the total number of polyhedra per gram dry weight in each soil sample.

Percent Co-occlusion. The percentage of AcE10 virus particles in the progeny polyhedra from individual dead larvae was determined according to Hamblin et al. (1990). Polyhedra from individual larvae were purified, the virions released by alkali treatment, the viral DNA purified and DNA restriction endonuclease fragment analysis performed using ethidium bromide staining or Southern hybridizations. DNA restriction endonuclease fragment analyses with the Trichoplusia ni nuclear polyhedrosis viral DNA were performed according to Hamblin et al. (1990).

Bioassay of Plant Tissue. On 4 June 1990, the test site was replanted with cabbage plants as per 1989. The test site was seeded with $T$. ni larvae four times during the growing season. On 26 June, 24 July, and 21 August 1990, one-third of the plants (about 900 plants) in the 0.1 -ha release area were seeded with four, six, and six thirdinstar T. ni larvae per plant, respectively. On September 14, five groups of 50 plants within the release area were inoculated with $\approx 100 \mathrm{~T} . n i$ eggs per plant.
After each seeding, the larvae were monitored daily, and, when an estimated $50 \%$ of the larvae had pupated, larval samples were collected individually in $30-\mathrm{ml}$ cups with rearing diet. The larvae were incubated in the laboratory until death or pupation.

\section{Results}

Evaluation of Soil Extraction and Bioassay Procedure. Based on the calibration line determined from the number of larval deaths with varying concentrations of polyhedra added to soil samples after extraction, the detection limit (one infection/30 larvae) was seven polyhedra per gram dry weight of soil (equivalent to one polyhedron per $100 \mathrm{~mm}^{2}$ of surface area). Replica samples exhibited a standard error of $\pm 20 \%$ in percent larvae killed. Based on larval response to varying concentrations of polyhedra added to soil samples before the extraction procedures, the efficiency of extraction was $\approx 24.6 \%$. Accordingly, the detection limit was $\approx 30$ biologically active polyhedra per gram dry weight of soil. The relationship between polyhedra per cup and percent infection was calculated to be $Y=1.8943+$ $1.4298 X(Y=$ response in probits; $X=\log$ of polyhedra per cup).

Soil Analysis Before Field Release. Bioassays of the 74 soil samples from the application area, buffer zone, and control plots resulted in the death of 47 of the 2,220 larval samples (30 larvae/ sample). The viral DNAs from all the cadavers exhibited the same EcoRI fragment pattern as was previously reported for the T. ni nuclear polyhedrosis virus (TnSNPV) (Smith \& Summers 1978). This was confirmed by DNA restriction fragment analyses of a TnSNPV isolate obtained from R. R. Granados (Boyce Thompson Institute). None of the larvae died with AcMNPV infections.

There were no records of a TnSNPV release in or near the experimental test site. The low-level soil contamination with the naturally occurring TnSNPV did not interfere with the analyses because first, TnSNPV and AcMNPV DNAs are readily identified based on EcoRI restriction endonuclease fragment analyses, and second, throughout the course of this experiment, polyhedral samples containing both TnSNPV and AcMNPV were never detected.

Aerosol Dispersal During Virus Application. During the first application, wind speed $1 \mathrm{~m}$ above ground level was estimated to be between 3 and $8 \mathrm{~km}$ per hour. For the second and third applications, the wind speeds, as measured with a portable weather station, were less than $3 \mathrm{~km}$ per hour throughout the application period.

During the first application of polyhedra, virus polyhedra deposition was detected in samples taken at the $30-\mathrm{m}$ distance of 9 of the 16 sectors (Table 1). At this distance $100 \%$ of the larvae 
Table 1. Percent death of T. ni neonate larvae fed on aerosol deposition plates

\begin{tabular}{|c|c|c|c|c|c|c|c|c|c|c|c|c|}
\hline \multirow{2}{*}{ Direction } & \multirow{2}{*}{ Spoke } & \multicolumn{11}{|c|}{ Distance from edge of application area, $\mathrm{m}$} \\
\hline & & 0 & 3 & 6 & 9 & 12 & 18 & 24 & 30 & 39 & 49 & 58 \\
\hline \multicolumn{13}{|c|}{ Release no. 1} \\
\hline \multirow[t]{4}{*}{ North } & $\mathbf{A}$ & 100 & 100 & 0 & 55 & 0 & 25 & 0 & 22 & & & \\
\hline & $\mathrm{B}$ & 100 & 5 & 0 & 5 & 25 & 0 & 5 & 0 & & & \\
\hline & $\mathrm{C}$ & 100 & 0 & 5 & 5 & 0 & 5 & 5 & 10 & & & \\
\hline & $\mathrm{D}$ & 77 & 0 & 0 & 15 & 0 & 6 & 25 & 20 & & & \\
\hline \multirow[t]{4}{*}{ East } & $E$ & 100 & 0 & 5 & 5 & 0 & 5 & 22 & 10 & & & \\
\hline & $\mathbf{F}$ & 0 & 4 & 25 & 17 & 0 & 0 & 0 & 0 & & & \\
\hline & $\mathrm{G}$ & 100 & 45 & 0 & 0 & 15 & 17 & 4 & 0 & & & \\
\hline & H & 34 & 25 & 5 & 25 & 0 & 4 & 0 & 0 & & & \\
\hline \multirow[t]{4}{*}{ South } & I & 100 & 0 & 0 & 0 & 4 & 0 & 4 & 10 & & & \\
\hline & $\mathbf{J}$ & 100 & 100 & 22 & 0 & 0 & 5 & 0 & 0 & & & \\
\hline & K & 100 & 100 & 0 & 0 & 5 & 15 & 5 & 40 & & & \\
\hline & L & 100 & 100 & 100 & 100 & 0 & 0 & 13 & 0 & & & \\
\hline \multirow[t]{4}{*}{ West } & $\mathbf{M}$ & 100 & 85 & 100 & 100 & 75 & 65 & 15 & 100 & & & \\
\hline & $\mathbf{N}$ & 100 & 100 & 75 & 100 & 100 & 100 & 25 & 0 & & & \\
\hline & 0 & 100 & 100 & 85 & 100 & 5 & 5 & 15 & 20 & & & \\
\hline & $\mathbf{P}$ & 100 & 100 & 5 & 0 & 15 & 5 & 65 & 10 & & & \\
\hline \multicolumn{13}{|c|}{ Release no. 2} \\
\hline \multirow[t]{4}{*}{ North } & A & 100 & 5 & 0 & 5 & 0 & 5 & 5 & 0 & 5 & & \\
\hline & B & 100 & 25 & 15 & 5 & 15 & 0 & 0 & 25 & 5 & & \\
\hline & C & 100 & 35 & 4 & 15 & 15 & 55 & 5 & 55 & 5 & & \\
\hline & $\mathrm{D}$ & 100 & 0 & 15 & 85 & 85 & 45 & 65 & 100 & 25 & 35 & 0 \\
\hline \multirow[t]{4}{*}{ East } & $\mathrm{E}$ & 100 & 100 & 100 & 100 & 85 & 85 & 55 & 55 & 15 & 35 & 0 \\
\hline & $\mathrm{F}$ & 100 & 55 & 75 & 5 & 27 & 15 & 5 & 0 & 25 & 0 & 0 \\
\hline & $\mathrm{G}$ & 100 & 0 & 5 & 0 & 5 & 0 & 15 & 0 & 5 & & \\
\hline & $\mathrm{H}$ & 100 & 0 & 15 & 5 & 5 & 0 & 0 & 35 & & & \\
\hline \multirow[t]{4}{*}{ South } & I & 100 & 100 & 15 & 5 & 5 & 0 & 5 & 5 & 0 & & \\
\hline & $\mathrm{J}$ & 100 & 85 & 5 & 15 & 75 & 25 & 0 & 0 & 0 & & \\
\hline & K & 100 & 100 & 15 & 5 & 55 & 0 & 5 & 0 & 5 & & \\
\hline & $\mathrm{L}$ & 100 & 25 & 25 & 0 & 5 & 15 & 5 & 5 & 5 & & \\
\hline \multirow[t]{3}{*}{ West } & $\mathbf{M}$ & 100 & 5 & 0 & 0 & 0 & 15 & 0 & 5 & 0 & & \\
\hline & $N$ & 100 & 85 & 100 & 3 & 0 & 5 & 15 & 0 & 15 & & \\
\hline & 0 & 100 & 0 & 0 & 5 & 0 & 0 & 5 & 0 & 0 & & \\
\hline • & $P$ & 100 & 0 & 5 & 0 & 15 & 5 & 5 & 5 & 5 & & \\
\hline \multicolumn{13}{|c|}{ Release no. 3} \\
\hline \multirow[t]{4}{*}{ North } & A & 100 & 20 & 47 & 47 & 27 & 17 & 27 & 7 & 47 & & \\
\hline & B & 100 & 20 & 17 & 17 & 57 & 17 & 17 & 17 & 4 & & \\
\hline & C & 100 & 20 & 17 & 17 & 27 & 37 & 17 & 17 & 60 & & \\
\hline & $\mathrm{D}$ & 100 & 20 & 17 & 0 & 27 & 0 & 0 & 32 & 17 & & \\
\hline East & $\mathrm{E}$ & 100 & 30 & 0 & 7 & 7 & 17 & 0 & 0 & 0 & & \\
\hline & $F$ & 100 & 100 & 7 & 7 & 0 & 7 & 0 & 17 & 4 & & \\
\hline & G & 100 & 100 & 7 & 41 & 0 & 0 & 7 & 0 & 0 & 50 & 7 \\
\hline & $\mathrm{H}$ & 100 & 100 & 37 & 0 & 0 & 77 & 77 & 0 & 17 & 2 & 10 \\
\hline South & I & 100 & 88 & 57 & 77 & 10 & 0 & 37 & 0 & 17 & 0 & 35 \\
\hline & $\mathrm{J}$ & 100 & 20 & 47 & 13 & 0 & 0 & 7 & 0 & 0 & & \\
\hline & $\mathrm{K}$ & 100 & 100 & 0 & 0 & 0 & 0 & 7 & 0 & 0 & & \\
\hline & $\mathrm{L}$ & 100 & 10 & 0 & 0 & 0 & 47 & 4 & 23 & 0 & & \\
\hline West & $\mathrm{M}$ & 100 & 60 & 10 & 27 & 0 & 17 & 0 & 23 & 7 & & \\
\hline & $\mathbf{N}$ & 100 & 20 & 7 & 0 & 0 & 43 & 0 & 0 & 19 & & \\
\hline & 0 & 100 & 20 & 7 & 0 & 0 & 47 & 0 & 0 & 0 & & \\
\hline & $\mathrm{P}$ & 100 & 30 & 17 & 0 & 7 & 0 & 17 & 4 & 0 & & \\
\hline
\end{tabular}

died only in the samples located directly downwind from the application area. During the second application, deposition of virus polyhedra was detected in samples taken at $49 \mathrm{~m}$ but not at $58 \mathrm{~m}$ from the outer edge of the application area (Table 1). During the third application, virus deposition was detected in both the 49- and 58-m samples.

Monitoring of Naturally Occurring Insects. $T$. $n i$ is a natural pest of cabbage in upstate New York and migrates into the area during the sum- mer. During the summers of 1989 and 1990, natural infestations of $T$. ni did not occur in the test site. However, natural infestations of Plutella xylostella and Pieris rapae were found in the test plot in both years. $P$. xylostella is a poor host for the AcMNPV, and, therefore, it is not surprising that we did not find any infected larvae. $P$. rapae is not a host for AcMNPV. No infected insects were detected outside of the application area.

Production of First-Generation Progeny Virus. The first dead larva was detected at $5 \mathrm{~d}$ after 
spray with each release. All of the larvae collected from the application area and control plot after the first and third applications died from AcMNPV infections. As a result of water condensation in the collection cups, a majority of the larvae from the second release died with bacterial infections and further analysis was not possible. However, to estimate total virus deposition from infected larvae, it was assumed that $100 \%$ of the seeded T. ni larvae (12,900 total) became infected and died after each of the three applications. Assuming the mean number of polyhedra produced per larvae was about $1.25 \times 10^{9}$ (Hamblin et al. 1990$), \approx 1.6 \times 10^{13}$ progeny virus polyhedra were deposited in the application area in 1989.

To estimate the percent of genetically altered virus in polyhedra deposited in the field during the lst $\mathrm{yr}$, the polyhedra from the individual field-collected larvae were subjected to DNA restriction endonuclease fragment analyses. Based on the analysis of 37 and 70 larval samples collected after the first and third applications, respectively, the progeny polyhedra contained an average of $42 \pm 17 \%$ genetically altered virions; the values ranged from 0 to $90 \%$. The distribution pattern and the mean percentage of occluded genetically altered virions is consistent with the distribution obtained in laboratory inoculations with polyhedra at concentrations $\approx 100$ times the $100 \%$ lethal dose (see Fig. $2 \mathrm{c}$ in Hamblin et al. 1990).

Soil Persistence Monitoring-1990. The soil samples from the application area in the spring of 1990 contained from 31 to 11,649 biologically active polyhedra per gram dry weight of soil. The mean value was $1,652 \pm 3,370$ polyhedra per gram dry weight of soil.

The samples taken from the buffer zone contained from 0 to 11,649 biologically active polyhedra per gram dry weight of soil with a mean value of $832 \pm 2,539$. Some movement of the polyhedra from the application area into the buffer zone was expected to occur as a result of the chopping and disking procedures used at the end of the 1989 season. Rain water and snow melt might have contributed to movement as well. The soil samples from the control plot were found to contain 31 to 6,739 polyhedra per gram dry weight. The mean number of polyhedra in the control site was $1,097 \pm 1,881$ polyhedra per gram dry weight of soil.

Polyhedra were purified from more than 500 individual larvae that died in the quantitation bioassay procedure with the soil extracts. Only 75 samples from the application area and 11 from the buffer zone contained sufficient numbers of polyhedra for analysis of viral DNA by ethidium bromide staining or Southern hybridizations. The polyhedra samples from the application area contained a mean of $9.0 \pm 19 \%$ genetically altered virions. The high standard deviation oc-
Table 2. Infection of $T$. ni larvae following natural contamination with soil-borne AcMNPV polyhedra

\begin{tabular}{ccc}
\hline Collection no. & No. of samples & $\begin{array}{c}\text { No. of AcMNPV } \\
\text { infected larvae }\end{array}$ \\
\hline 1 & 130 & 0 \\
2 & 500 & 0 \\
3 & 499 & 4 \\
4 & 498 & 14 \\
Total & 1,627 & $18(1.1 \%)$ \\
\hline
\end{tabular}

curred because only 19 of the 75 samples contained detectable levels of genetically altered viral DNA. The 19 positive polyhedra samples contained from 4 to $70 \%$ genetically altered virions and had a mean of $35 \pm 23 \%$. The samples from the buffer zone gave comparable values. However only 3 of the 11 samples contained detectable levels of genetically altered viral DNA.

Polyhedral Contamination of Plant Tissue1990. During the summer of the 2nd yr (1990), field monitoring of larvae that were seeded onto the plants detected no larval deaths. When a total of 130 and 500 larvae from the first and second larval releases, respectively, were reared in the laboratory, no viral deaths occurred (Table 2). However, 7 of 499 (1.4\%) larvae collected from the third larval release died of virus.

Because so few infected larvae were obtained in these planned releases, a fourth larval release was performed. Based on the soil extraction data, five areas in the application site were identified as to which had the highest concentration of polyhedra in the soil. Fifty plants at each site were inoculated with 100 eggs. In this way we were able to introduce $\approx 25,000$ larvae into areas where the soil contained high concentrations of polyhedra. Again the larvae were carefully monitored with no evidence of larval infections. At 50\% pupation, 498 larvae were collected in diet cups and incubated in the laboratory until death or pupation. Only $7(1.4 \%)$ larvae died of virus, thereby confirming our earlier data (Table 2).

Soil Persistence Monitoring-1991. The 1991 soil samples taken from the application area contained 31 to 11,649 polyhedra per gram dry weight. The mean value was $1,671 \pm 3,274$ biologically active polyhedra per gram dry weight of soil. The soil samples taken from the buffer zone contained 0 to 460 polyhedra per gram dry weight, with a mean of $63 \pm 83$ polyhedra per gram dry weight of soil.

As in 1990, polyhedra were purified from individual larvae that died in the quantitation bioassay procedure. Viral DNA restriction fragment analyses were successfully performed on $84 \mathrm{sam}$ ples from the application area and 10 samples from the buffer zone. The mean percent genetically engineered virions in the 84 application 
area polyhedral samples was $6 \pm 14 \%$. Eighteen samples contained detectable levels of genetically altered viral DNA ranging from 6 to $64 \%$, with a mean of $30 \pm 16 \%$. The 10 samples from the buffer zone contained no detectable genetically altered viral DNA.

\section{Discussion}

Based on the aerosol dispersal data (Table 1), containment of the polyhedra inocula to the 0.8 -ha test site was not achieved. It should be appreciated that the bioassay procedure maximized the detection of polyhedra deposition $(0.6$ polyhedra $/ \mathrm{mm}^{2}$ ). The quantitative nature of the bioassay data, however, is questionable because a single infected larva could produce secondary inoculum for the other nine larvae. Despite this limitation, the data from the first and second releases are consistent with the prevailing wind direction during the application and the percent death generally decreased with increasing distance from the application area. Based on these observations, it is considered that containment was probably achieved within a 2-ha area.

Based on laboratory studies of the co-occlusion process (Hamblin et al. 1990), it was considered that under field conditions a polyhedrin-minus recombinant virus could not persist in a baculovirus population during successive passages of virus from one insect to another. In order to evaluate this hypothesis, a virus population had to be created that contained measurable levels of occluded, polyhedrin-minus virus. To produce polyhedra containing approximately equal numbers of wild-type and Ac-E 10 virions, T. ni larvae must be infected with polyhedra containing equal numbers of the two virus types at concentrations $\approx 100$ times the $\mathrm{LD}_{100}$ (Hamblin et al. 1990). These conditions maximize the probability of coinfection of individual larvae and larval cells with both virus types. Accordingly, the polyhedra inoculum used in the field release contained $48 \%$ genetically altered virus particles, and the application rate was $7.4 \times 10^{12}$ polyhedra per hectare.

Even at this high dosage, the first larval deaths were not detected until $5 \mathrm{~d}$ after spraying. The AcMNPV is considered highly pathogenic to $T$. ni larvae. This relatively lengthy time to first death illustrates the need to genetically enhance the pesticidal properties (time to cessation of feeding or death) of baculovinuses such as AcMNPV in order to achieve acceptable agronomic standards of pest control.

Based on the number of progeny polyhedra produced in $T$. ni larvae under laboratory conditions (Hamblin et al. 1990), it was estimated that a minimum of $1.6 \times 10^{13}$ progeny polyhedra were produced by the 12,900 test larvae in the application area. According to Buckman \& Brady (1969), the soil in the top $15 \mathrm{~cm}$ of the 0.1 -ha application area would weigh in the order of $2.27 \times 10^{8}$ grams dry weight. Accordingly, the application area was predicted to contain $\approx 70,500$ polyhedra per gram dry weight of soil. The 50-fold difference between the estimated total number of polyhedra and the estimated number of biologically active $(1,652-1,671)$ polyhedra can be partially accounted for based on the high rate of UV light inactivation of polyhedra on leaf surfaces (Evans 1986). A comparison of the number of biologically active polyhedra in the control and application area in year 2 indicates that the occlusion of the genetically altered virions did not affect in any measurable way the biological persistence of polyhedra in the soil.

It generally has been accepted that soil contaminated with baculoviruses will contaminate plant tissues leading to subsequent rounds of infection (Jaques 1974, Young \& Yearian 1979). Because the soil in the application area contained high levels of biologically active polyhedra, we assumed that the soil would act as an excellent source of virus inoculum on the new plants. The low percentage of infected larvae suggests that contamination of the cabbage foliage with the AcMNPV polyhedra might not be an effective means of natural transmission. If foliar contamination did occur, it is conceivable that the polyhedra were inactivated by sunlight (Evans 1986) before the seeding of larvae.

It should be recognized that in the absence of additional larval infections in the test site, the polyhedra monitored in years 2 and 3 were only the progeny polyhedra produced in year 1 . Accordingly, it is not surprising that the mean concentration of polyhedra in years 2 and 3 were similar. Additionally, the percent genetically altered virus particles occluded in the progeny polyhedra produced by larvae in the soil extraction bioassays in year 2 and 3 are also very similar. Clearly, there was no significant reduction in the number of biologically active polyhedra between years 2 and 3 . Persistence of baculovirus polyhedra in soil is a well-documented phenomenon (Thomas et al. 1972, Jaques 1975, Thompson et al. 1981).

A high number of larval samples contained undectable or low concentrations of progeny polyhedra. Several factors contributed to this phenomenon. All of the laboratory assays used neonate larvae. The infection and death of firstor second-instar larvae would naturally produce relatively few progeny polyhedra. Additionally, the number of polyhedra produced during the co-infection/co-occlusion process in larvae is lower than with wild-type infections (Hamblin et al. 1990). Also, at multiplicities of infection of one infectious virion per larva, approximately one-third of the larvae become infected with only the genetically altered virus (producing no polyhedra) (Hamblin et al. 1990). Under these same conditions, approximately one-third of the 
larvae become infected with both virus types. These are considered to be the major factors contributing to the low number of progeny virus populations containing both virus types.

The major factor in determining the $6-9 \%$ occlusion of genetically altered virions in the progeny polyhedra samples was obviously the concentration of inoculum. Larvae infected in the field during year one obtained a high inoculum dosage resulting in a high mean percentage $(42 \%)$ of genetically altered virions in the progeny polyhedra. In the surface contamination bioassays with the soil extracts, the larvae could ingest the number of polyhedra present in 0.25 gram of soil. Ingestion of 4-500 polyhedra during surface feeding is considered a low inoculum level with a low probability of co-infection of individual larval cells (Hamblin et al. 1990). Accordingly, the progeny polyhedra population contained small amounts $(6-9 \%)$ of the genetically altered virus. However, it should be recognized that the polyhedra in the soil that were produced in year 1 will persist for many years. The co-occlusion strategy limits the persistence of a polyhedrin-minus virus in a cycling virus population but does not alter environmental persistence.

The development and commercialization of genetically enhanced baculovirus insecticides clearly offers an important alternative to certain chemical pesticides. The registration of these products as pesticides will require special considerations based on their reproductive potential and nature of the genetic enhancement. Because of the dearth of information concerning the ecology of baculoviruses, it currently would appear unwise to release a genetically enhanced form that has the potential to displace natural virus populations. Data collected in the current study indicate that the co-occlusion strategy may be used to address this problem. However, repeated commercial applications of co-occluded baculovirus pesticides at a single site could lead to extremely high levels of the genetically altered virus in the soil. These high levels would persist for years, and the ecological consequences of this are currently unclear.

Additional studies are being undertaken to improve the co-occlusion process and to develop alternative strategies. Laboratory tests with preoccluded baculovirus inocula (Wood et al. 1993, Wood \& Hughes 1993) indicated that there would be zero environmental persistence under field conditions. Clearly, careful evaluation of field release data will be required to assess the benefits and potential problems associated with this and other field release strategies.

\section{Acknowledgments}

These investigations were partially supported by grant CR-815830-01 from the U.S. Environmental Pro- tection Agency. We want to thank Ralph Hardy for his advice and support in conducting this experiment. We also wish to thank M. Hamblin, M. Kroening, S. Krasnoff, K. Trotter, L. Krupka, M. Nobel, and W. Wilsey for their competent technical assistance.

\section{References Cited}

Bishop, D.H.L., P. F. Entwistle, I. R. Cameron, C. J. Allen \& R. D. Possee. 1988. Field trials of genetically-engineered baculovirus insecticides, pp. 143-179. In M. Sussman, C. H. Collins, F. A. Skinner \& D. E. Stewart-Tull [eds.], The release of genetically-engineered micro-organisms. Academic, New York.

Buckman, H. O. \& N. C. Brady. 1969. The nature and properties of soils. Macmillan, London.

Carbonell, L. F., M. R. Hodge, M. D. Tomalski \& M. K. Miller. 1988. Synthesis of a gene coding for an insect-specific scorpion neurotoxin and attempts to express it using baculovirus vectors. Gene 73: 409418.

Cunningham, J. C. 1982. Field trials with baculoviruses: control of forest insect pests, pp. 335-386. In E. Kurstak [ed.], Microbial and viral pesticides. Marcel Dekker, New York.

Evans, H. F. 1986. Ecology and epizootiology of baculoviruses, pp. 89-132. In R. R. Granados \& B.A. Federici [eds.], The biology of baculoviruses, vol. 2. CRC, Boca Raton, FL.

Groner, A. 1986. Specificity and safety of baculoviruses, pp. 177-202. In R. R. Granados \& B. A. Federici [eds.], The biology of baculoviruses, vol. 1 . CRC, Boca Raton, FL.

Hamblin, M., N.A.M. van Beek, P. R. Hughes \& H. A. Wood. 1990. Co-occlusion and persistence of a baculovirus mutant lacking the polyhedrin gene. Appl. Environ. Microbiol. 56: 3057-3062.

Hammock, B. D., B. C. Bonning, R. D. Possee, T. N. Hanzlik \& S. Maeda. 1990. Expression and effects of the juvenile hormone esterase in a baculovirus vector. Nature (Lond.) 344: 458-461.

Huber, J. 1986. Use of baculoviruses as pesticides, pp. 181-202. In R. R. Granados \& B. A. Federici [eds.], The biology of baculoviruses, vol. 2. CRC, Boca Raton, FL.

Jaques, R. P. 1974. Occurrence and accumulation of the granulosis virus of Pieris rapae in treated field plots. J. Invertebr. Pathol. 23: 351-359.

Jaques, R. P. 1975. Persistence, accumulation, and denaturation of nuclear polyhedrosis and granulosis viruses, pp. 90-99. In M. Summers, R. Engler, L. A. Falcon \& P. V. Vail [eds.], Baculoviruses for insect pest control: safety considerations. Am. Soc. Microbiol., Washington, DC.

Leisy, D. J., G. F. Rohrmann \& G. S. Beaudreau. 1984. Conservation of genome organization in two multicapsid nuclear polyhedrosis viruses. J. Virol. 52: 699-702.

Leisy, D. J. \& N. van Beek. 1992. Baculoviruses: possible alternatives to chemical pesticides. Chem. Ind. (Lond.) 7: 233-276.

Maeda, S. 1989. Increased insecticidal effect by a recombinant baculovirus carrying a synthetic diuretic hormone gene. Biochem. Biophys. Res. Comm. 165: 1177-1183.

Maeda, S., S. L. Volrath, T. N. Hanzlik, S. A. Harper, K. Majima, D. W. Maddox, B. D. Hammock \& E. 
Fowler. 1991. Insecticidal effects of an insectspecific neurotoxin expressed by a recombinant baculovirus. Virology 184: 777-780.

Merryweather, A. T., U. Weyer, M.P.G. Harris, M. Hirst, T. Booth \& R. D. Possee. 1990. Construction of genetically engineered baculovirus insecticides containing the Bacillus thuringiensis ssp. kurstaki HD-73 delta endotoxin. J. Gen. Virol. 71: 1535-44.

Miller, D. W. 1988. Genetically engineered viral insecticides: practical considerations, pp. 405-421. In P. A. Hedin, R. M. Hollingworth \& J. J. Mann [eds.], Biotechnology for crop protection. Am. Chem. Soc., Washington, DC.

Smith, G. E. \& M. D. Summers. 1978. Analysis of baculovirus genomes with restriction endonucleases. Virology 89: 517-527.

Stewart, L.M.D., M. Hirst, M. L. Ferber, A. T. Merryweather, P. J. Cayley \& R. D. Possee. 1991. Construction of an improved baculovirus insecticide containing an insect-specific toxin gene. Nature (Lond.) 352: 85-88.

Thomas, E. D., C. F. Reichelderfer \& A. H. Heimpel. 1972. Accumulation and persistence of a nuclear polyhedrosis virus of the cabbage looper in the field. J. Invertebr. Pathol. 20: 157-164.

Thompson, C. G., D. W. Scott \& B. E. Wickman. 1981. Long-term persistence of the nuclear polyhedrosis virus of the Douglas-fir tussock moth, Orgyia pseudotsugata (Lepidoptera: Lymantriidae), in forest soil. Environ. Entomol. 10: 254-255.
Tomalski, M. D. \& L. K. Miller. 1991. Insect paralysis by baculovirus-mediated expression of a mite neurotoxin gene. Nature (Lond.) 352: 82-85.

Wood, H. A. 1980. Autographa californica nuclear polyhedrosis virus-induced proteins in tissue culture. Virology 102: 21-27.

1991. Development of genetically enhanced baculovirus pesticides. pp. 69-76. In K. Maramorosch [ed.], Biotechnology for biological control of pests and vectors. CRC, Boca Raton, FL.

Wood, H. A. \& R. R. Granados. 1991. Genetically engineered baculoviruses as agents for pest control. Annu. Rev. Microbiol. 45: 69-87.

Wood, H. A. \& P. R. Hughes. 1993. Environmental and commercial evaluations of genetically engineered baculovirus pesticides. pp. 261-281. In L. Kim [ed.], Advanced engineered pesticides. Marcel Dekker, New York.

Wood, H. A., K. M. Trotter, T. R. Davis \& P. R. Hughes. 1993. Per os infectivity of preoccluded virions from polyhedrin-minus recombinant baculoviruses. J. Invertebr. Pathol. 62: 64-67.

Young, S. Y. \& W. C. Yearian. 1979. Soil applications of Pseudoplusia NPV: Persistence and incidence of infection in soybean looper caged on soybean. Econ. Entomol. 8: 860-864.

Received for publication 22 April 1993; accepted 28 October 1993. 